\title{
SEGMENT FRAZEOLOGICZNY \\ I PAREMIOLOGICZNY \\ POLA KONCEPTUALNEGO \\ „PRACOWITOŚĆ”/ «ТРУДОЛЮБИЕ» \\ W JĘZYKU POLSKIM I ROSYJSKIM
}

\author{
ANDRZEJ SITARSKI
}

We współczesnym językoznawstwie do jednego z podstawowych problemów badawczych należy identyfikacja i zróżnicowanie źródeł wiedzy, które określane są przez różne jednostki językowe, między innymi przez frazeologizmy i paremie.

Niniejszy artykuł stanowi próbę syntezy frazeologii i paremiologii z lingwistyką kognitywną z uwzględnieniem założeń językoznawstwa konfrontatywnego. Proponuje się w nim analizę kształtowania segmentu frazeologicznego i paremiologicznego pól konceptualnych „Pracowitość” w języku polskim i „Трудолюбие” w języku rosyjskim z uwzględnieniem aspektu etnokulturowego. Lingwistyka kognitywna, jak wiadomo, wychodzi z założenia, iż konceptualizacja określonej przestrzeni mentalnej utrwalana jest przy pomocy znaków językowych, dlatego też problem organizacji konceptualnej języka w określonej przestrzeni możliwe jest poprzez analizę semantyki oraz jej użycia w określonej przestrzeni etnokulturowej.

Pod pojęciem pola konceptualnego zgodnie $\mathrm{z}$ definicją zaproponowaną przez L.W. Łajenko rozumieć będziemy «...целенаправленную систему гетерогенных средств представления (понимания) смысла, включающаю компоненты, объединенные интегративным смысловым признаком, актуализирующимся функционально в этих элементах» (Лаенко, 2013: 34). Wypada zwrócić uwagę na fakt, iż pole konceptualne reprezentuje fragment systemu konceptualnego określonego etnosu, w którym utrwalana jest etniczna skala wartości oraz funkcjonujące kody kultu- 
rowe. Uwzględniając fakt, iż jednostką leksykonu etnokulturowego jest koncept, który obejmuje z zasady więcej niż jeden znak językowy, to ilość reprezentacji językowych takiego konceptu jest uwarunkowana rozumieniem pojęcia odnoszącego się do danego konceptu w aspekcie etnokulturowej świadomości językowej. Lingwistyka kognitywna w swoich założeniach metodologicznych podkreśla ścisły związek języka i myślenia, skupiając uwagę na interpretacji mechanizmów werbalizacji i kategoryzacji konceptów, czyli reprezentacji konceptów poprzez określone znaczenia, formy gramatyczne, czy też struktury syntaktyczne. Podkreślić należy, iż analiza kognitywna znaczenia obejmuje cały kompleks wiedzy oraz doświadczeń pozajęzykowych etnosu lingwokulturowego, zbiór informacji językowej i ekstralingwalnej. Tak więc, u podstaw podejścia kognitywnego do znaczenia leży opis struktury określonego konceptu, determinującego jego proces nominacji, objaśniając nominacje obiektów rzeczywistości, których nazwy są utrwalone w systemie leksykalnym języka. Walentyna Apresjan zauważa, że «... часть концептуальной информации имеет языкову привязку, т.е. средства языкового выражения, но часть этой информации представляется в психике принципиально иначе, т.е. ментальными репрезентациями другого типа - образами, картинками. Исследованию подлежит именно концептуаьный слой семантики - уровень ментальных сущностей, которые структурируют и предопределеяют содержание лексических единиц» (Апресян і Апресян, 1993: 34-36).

Koncept „Pracowitość”/«Трудолюбие» reprezentuje strukturę wielowarstwową, którą tworzy jego poziom ,przyrodzony” (wykonywanie pracy przez człowieka), etyczny i etnokulturowy, odzwierciedlające dominujące cechy pracowitości lub będącej w opozycji do niej - lenistwa.

W niniejszym opracowaniu scharakteryzowany będzie koncept „Pracowitość”/ /«Трудолюбие» utrwalony w świadomości językowej Polaków i Rosjan z punktu widzenia przedstawionych założeń lingwistyki kognitywnej. Obiektem analizy będą polskie i rosyjskie frazeologizmy oraz przysłowia, będące źródłem werbalizacji omawianego konceptu, wyrażające w swoich treściach specyfikę kulturową i etniczną Polaków i Rosjan. Modelowanie segmentu konceptualnego pola „Pracowitość/Tpyдолюбие” w obu językach pozwala określić jego cechy semantyczno-kognitywne oraz jego specyfikę etnokulturową. Zaproponowana charakterystyka wskazanego konceptu oparta została na materiale frazeologicznym i paremiologicznym języka rosyjskiego i polskiego. W rezultacie treść anlizowanego konceptu odtwarza świadomość językową dwóch badanych kultur językowych w aspekcie naiwnego, chociaż również zdroworozsądkowego językowego obrazu utrwalonego w mentalności dwóch narodów. Trudno nie zgodzić się z myślą rosyjskiego badacza O. Poczepcowa, który konstatuje, iż «... во фразеологизмах (также и паремиях) хранятся данные, способствующие определению контуров наивной картины мира определенного этноса. В них концептуализированы передающиеся из поколения в поколение и, таким образом, формирующие мировидение и миропонимание, эталоны и ментальные стереотипы национальной куль- 
туры.» (Почепцов, 1990: 6). Nie ulega wątpliwości, że frazeologizmy i paremie posiadają wykładniki parametrów myślenia na poziomie języka i jego użycia w aktach komunikacyjnych.

Bazę materiałową do niniejszego artykułu tworzą przykłady frazeologizmów zaczerpnięte z Польско-русского фразеологического словаря К. Гюлумянц (2004), natomiast przykłady przysłów wyekscerpowane zostały z Rosyjsko-polskiego i polsko rosyjskiego słownika przysłów R. Stypuły (1974). Ogółem analizie poddano 289 przykładów polskich i 274 rosyjskich. z których tylko nieznaczna cześć została przytoczona w niejszym artykule.

W. Doroszewski w Stowniku języka polskiego pracowitość określa jako zamiłowanie, zdolność do pracy, wytrwałość w pracy" (Doroszewski, 1958/1969: 1402-1403), natomiast kontrastujące z pracowitością lenistwo to niechęć do pracy, opieszałość, gnuśność, nieróbstwo, próżniactwo (Doroszewski, 1958/1969: 87). Podobne znaczenie leksemu трудолюбие proponuје Большой толковый словарь русского языка pod red. S.A. Kuzniecowa: любовь к труду, усердие в труде (Кузнецов, 1998: 1348), natomiast лень - to: отсутствие желания работать, делать что-л (Кузнецов, 1998: 493).

Zaproponowana w niniejszym artykule charakterystyka konceptu „Pracowitość”/ /«Трудолюбие» w obszarze polskiej i rosyjskiej przestrzeni lingwokulturowej uwzględnia interpretację pojęcia «definicji kognitywnej» zaproponowanej przez J. Bartmińskiego. Należy podkreślić, iż definicja kognitywna w ujęciu Bartmińskiego za cel glówny przyjmuje zdanie sprawy z pojmowania przedmiotu przez mówiących danym językiem, tj. ze spososbu utrwalonej społecznie i dającej się poznać poprzez język i użycie języka wiedzy o świecie, kategoryzacji jego zjawisk, ich charakterystyki i wartościowania (Bartmiński, 2006: 42).

Zanim przejdziemy do analizy zebranego materiału warto podkreślić, iż we współczesnych badaniach obiektów językowych, szczególnie w linwistyce kognitywnej, podejście antropocentryczne stanowi dominującą ich cechę, do których należy odnieść między innymi język wartości, określający zainteresowania człowieka. Kierunek antropocentryczny w badanich współczesnej lingwistyki przesądza i formułuje tzw. podejście aksjologiczne do języka, rozpatrywanego jako odbicie systemu ludzkich wartości, w jego wariantach charakterystycznych dla różnych odmian grup społecznych.

W zebranym rosyjskim i polskim materiale frazeologicznym oraz paremiologicznym w obszarze pola konceptualnego „Pracowitość” odnotowujemy przykłady struktur komparatywnych z komponentem zoonimicznym, np. трудолюбивый как пчела, трудолюбивый как муравей, pol.: pracowity jak pszczoła (pszczótka), pracowity jak mrówka, pracowity jak wót, obok których wypada wymienić kolokacje: ломовая лошадb, wót roboczy, których negatywna konotacja wartościująca określa człowieka uległego, obarczanego zazwyczaj zbyt ciężką pracą.

Człowieka leniwego w języku rosyjskim określają następujące kolokacje: гнусный лентяй, неисправимый лентяй, отъявленный лентияй, w języku pol- 
skim: śmierdzacy leń, patentowany leń (leniuch), niebieski ptak, robotnik majowy, a także paremie: ros.: велик телом, да мал делом, Велика Федора, да дура, а Иван мал, да удал, ленивого отправлять только за смертью в лес, pol. tylko go po śmierć posłać, cóż z tego, że wielki, kiedy do roboty niezdatny. O człowieku obdarzonym zdolnościami w zakresie wykonywanej pracy informują $\mathrm{w}$ języku rosyjskim frazeologizmy: мастер на все руки, мастер своего дела, у кого-л. золотые руки, w języku polskim: złota rączka, dobra (solidna) firma, z kolei o człowieku nie radzącym sobie z wykonaniem pracy można powiedzieć: ros. мастер-ломастер, pol. ktoś ma dwie lewe ręce, majster-klepka.

Do najbardziej obrazowych z punktu widzenia wartościowania wykonywanej przez człowieka pracy można odnieść kolokacje werbo-adwerbialne, np. ros. работать до кровавого (седьмого) пота, работать до упаду, расшибиться (разбиваться) в лепешку, работать не покладая рук, работать в поте лица, работать засучив рукава, pol. krwawo pracować, zapracowywać się/zapracować się na śmierć, stawać na uszach, urabiać (urobić) sobie ręce po tokcie, pracować w pocie czoła. Pracować (robić) światek i piatek.

Zarówno w rosyjskim, jak i polskim obszarze lingwokulturowym znajdujemy frazeologizmy wartościujące różne aspekty językowej realizacji konceptualnego atrybutu pracowitości, do którego można odnieść zmęczenie jako negatywnego skutku ciężkiej pracy, np. w ros.: валиться (падать) с ног, падать от усталости, ного под собой не чуствовать (не чуять, не слышать), едва держаться на ногах, быть еле живым, выбиваться/выбиться из сил, pol.: padać zе zтесczenia, lecieć (padać) z nóg, padać na pysk (na gębę), być na ostatnich obrotach, orać nosem, gonić resztkami, (ostatkami, ostatkiem) sit.

W obu badanych językach w opozycji do pracowitości, czasami nawet realizowanej z przekroczeniem granic rozsądku, odnajdujemy frazeologizmy określające lenistwo. Szereg synonimiczny z dominantą ,człowiek leniwy” realizują następujące przykłady, w j. ros.: стдеть сложа руки, сидеть именинником (барином), лежать на боку, гранить мостовую, слоняться (шататься) без дела, гонять лодыря, бить баклуши, считать ворон (галок), лежать на плечи, лежать ничком (пластом), плевать в потолок, хлопать ушами, зевать по сторонам. W polskim językowym obrazie człowieka leniwego odnotowano, między innymi, następujące jednostki frazeologiczne: boki obijać, siedzieć z zatożonymi rękami, zbijać baki, szlifować bruki (obijać się po bruku), podpierać piece $w$ domu, leżéc plackiem, pluć i tapać, leżeć do góry brzuchem (pępkiem do góry), chodzić (łazić, watęsać się) z kąta w kąt, szukać dnia wczorajszego, zalegać/zależeć pole, mieć labę.

W badanym polu konceptualnym występują odnotowano jednostki frazeologiczne i paremiololgiczne, których sens aksjologiczny określa lekceważący stosunek człowieka do pracy, np.: ros. палец о палец не ударить, пальцем не шевельнуть, море по колено кому-л., плевать/наплевать (чихать/начихать) на что-л. (на все), не запятнать себя трудом, руки чьи-л. никогда не осквернили себя paбomoŭ, pol. palcem o palec nie uderzyć, (nie stuknać), nie kiwnać palcem 
w bucie, palcem nie ruszyć, ktoś ma coś (wszystko) w nosie), praca się nie hańbić/nie pohańbić.

Wykonywana przez człowieka praca nie zawsze przynosi pozytywne rezultaty, bywa że wysiłek włożony w wykonanie określonych czynności jest nieskuteczny, nie przynosi żadnych korzyści. Rekcją językową, wartościującą często ironicznie bezużyteczny wysiłek człowieka są następujące frazeologizmy i paremie: ros. пелевание (переливать) из пустого в порожнее, лить (возить) воду в колодец, возить дрова в лес, мартышкин труд, носить воду решетом, толочь воду в ступе, в колодец водь не льют, в Тулу со совим самоваром не ездят, ломиться в открытую дверь, pol. Czerpać (nosić) wodę sitem (przetakiem), wozić drwa (szyszki) do lasu, wozić wodę do studni, zawracanie Wisty kijem, kręcić bicz z piasku, głupiego robota, morzu wody dolewać, przelewanie (przelewać) z pustego w próżne, wyważać (wywalać) drzwi otwarte.

Przytoczone powyżej przykłady kontrastują z grupą frazeologizmów, których konotacja aksjologiczna jest jednoznacznie dodatnia, ponieważ zawarta w nich ocena rezultatu pracy wykonanej przez człowieka jest pozytywna, ros.: на все сто, ня ять, комар носа (носу) не подточит, что и не придерешься, любо-дорого смотреть, pol.: ż mucha nie siada, na medal, na sto dwa, na tip-top.

Na podstawie przytoczonych przykładów frazeologizmów oraz paremii werbalizujących koncept „Pracowitość”/«Трудолюбие» w obszarze rosyjskiego i polskiego etnosu lingwokulturowego należy stwierdzić, iż zaprezentowane treści wybranych obiektów językowych funkcjonujących w ramach analizowanego pola konceptualnego w obu językach kreują świadomość językową Rosjan i Polaków, formułując naiwny, ale także zdroworozsądkowy obraz charakteryzowanego konceptu. Okazuje się, iż obie kultury językowe w kategoryzowanym polu konceptualnym są bliskie sobie. Zarówno w języku rosyjskim, jak i polskim znajdujemy przykłady opisu człowieka pracowitego i leniwego, jego stosunku do pracy, także jej skutków i jakości oraz takich przymiotów człowieka jak pracowitość i lenistwo. Istotne dla zaprezentowanego materiału faktograficznego jest przede wszystkim to, że jego sens znaczeniowy przeniknięty jest ideą antropocentryczności oraz cechą aksjologiczną. Podkreślić również należy, że zaprezentowana $\mathrm{w}$ artykule próba modelowania frazeologiczno-paremiologicznego segmentu pola konceptualnego «Трудолюбие»/ /,Pra-cowitość” w języku rosyjskim i polskim pozwala określić nie tylko jego strukturę semantyczno-kognitywną, ale także zwrócić uwagę na jego specyfikę kulturową w zakresie porównywanych języków.

\section{Bibliografia}

Апресян, В.Ю. і Ю.Д. Апресян. 1993. „Метафоры в семантическом предствалении эмоций”. Вопросы языкознания 3. 27-35.

Bartmiński, J. 2006. Językowe podstawy obrazu świata. Lublin: Wydawnictwo UMCS. 
Doroszewski, W. 1958/1969. Stownik języka polskiego. Warszawa: Państwowe Wydawnictwo „Wiedza Powszechna" / Państwowe Wydawnictwo Naukowe.

Гюлумянц, К. 2004. Польско-русский фразеологический словарь. Минск: Экономпресс.

Кузнецов, С.А. 1998. Большой толковылй словарь русского языка. Санкт-Петеребург: Норинт.

Лаенко, Л.В. 2012. „Концептуальное поле как способ организации лексикона английского языка”. Вестник ВГУ, Серия: Лингвистика и межкультурная комуникация 1. 29-35.

Почепцов, О.Г. 1990. „Языковая ментальность: способ представления мира”. Bonpocbl языкознания 6. 110-122.

Stypuła, R. 1974. Stownik przysłów rosyjsko-polski i polsko-rosyjski. Warszawa: Wiedza Powszechna. 